IJMS 17 (1), 1-18 (2010)

\title{
FOREIGN INVESTMENT, GOVERNMENT EXPENDITURE, AND ECONOMIC GROWTH IN MALAYSIA
}

\author{
FATIMAH SAID \\ ZARINAH YUSOF \\ SAAD MOHD SAID \\ AHMAD FARID OSMAN \\ Faculty of Economics and Administration \\ Universiti Malaya
}

\begin{abstract}
This study uses the ordinary least squares technique to examine the effect of foreign investment and government expenditure on the growth in GDP per capita in Malaysia over the period 1978-2005. The regression results showed that the growth of export and ratio of government expenditure to GDP are the driving forces in enhancing the economic growth in Malaysia. Foreign investment and previous year real income per capita growth depict positive impact, whereas population growth exerts a negative impact on economic growth.
\end{abstract}

Keywords: Foreign investment; government expenditure; economic growth.

\begin{abstract}
ABSTRAK
Kajian ini menggunakan teknik ganda dua terkecil biasa untuk mengkaji kesan pelaburan asing dan perbelanjaan kerajaan ke atas pertumbuhan KDNK per kapita Malaysia dalam tempoh 1978-2005. Keputusan regresi yang diperoleh menunjukkan pertumbuhan eksport dan nisbah antara perbelanjaan kerajaan dengan KDNK merupakan penjana utama pertumbuhan ekonomi Malaysia. Pelaburan asing dan pertumbuhan pendapatan benar per kapita tahun lepas memberi kesan positif, manakala pertumbuhan penduduk memberi kesan negatif ke atas pertumbuhan ekonomi Malaysia.
\end{abstract}

Kata kunci: Pelaburan asing; perbelanjaan kerajaan; pertumbuhan ekonomi. 


\section{Introduction}

In the economic literature, foreign direct investment (FDI) is often seen as an important catalyst for economic growth. Several means have been identified to emphasise on the role of FDI in promoting economic growth, especially for developing countries (De Mello, 1997). Given the lack of knowledge and skills to develop own indigenous technology, developing countries may depend on imported technology obtained from developed countries. FDI is one of the important vehicles of technology transfer from developed countries to developing countries. Through technology transfer, FDI is expected to induce technological progress and promote long term growth in the host country.

FDI also enhances economic growth of host countries through capital accumulation and human capital augmentation. FDI adds to the existing domestic capital stock and hence contributes to economic growth similar to the contribution of domestic capital investment. Existing stock of human capital in the host country is augmented through knowledge transfer, labour training and skill acquisition and diffusion from foreign multinational firms to domestic firms.

Public expenditure measures the extent of government intervention in the economy. It has been used as a fiscal policy tool to improve economic performance due to fluctuations in aggregate expenditure. However, its effect in promoting economic growth depends on the efficiency of the public sector (Levine \& Renelt, 1992). A large and efficient public sector would provide significant spillover effects which would enhance and stimulate investment in the private sector and generate economic growth. On the other hand, large and inefficient public sector would impede economic growth through excessive bureaucracy and regulations that distort private decisions.

A rise in public spending may also result in the crowding out effect which increases the equilibrium interest rate, reduces private investment and hence lowers overall productivity (Barram \& Ward, 1993; Giannaros, Kolluri, \&

- Panik, 1999). An increase in government expenditure which is financed through an increase in taxes would reduce the benefits of taxpayers and eventually lower the rate of economic growth (Le \& Suruga, 2005).

Various studies had been carried out, either in Malaysia or other countries, to investigate the determinants of economic growth by including FDI and/or government expenditure as explanatory variables in the model. However, existing studies in Malaysia only investigated the impact of either foreign investment or government expenditure on Malaysian economic growth separately. To our knowledge, none of the studies have included simultaneously foreign investment and government expenditure as fiscal

2 IJMS 17 (1), 1-18 (2010) 


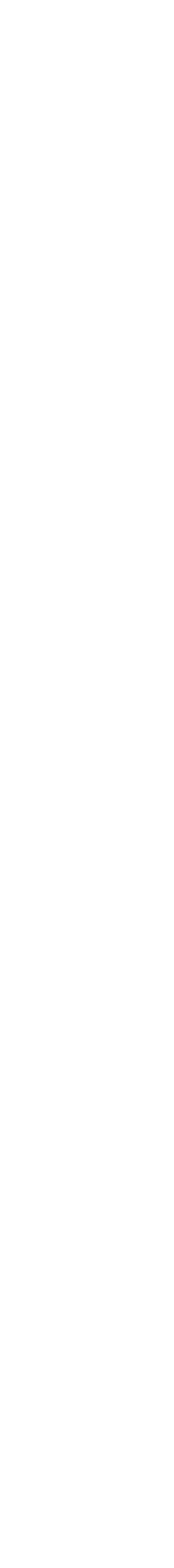

indicators in their models. Hence, the objective of this study was to examine the impact of foreign investment and government expenditure on Malaysian economic growth during 1978-2005. The inclusion of both variables enables us to identify which contributes more to Malaysian economic growth.

This paper is divided into six sections. An overview of foreign investment and public expenditure in Malaysia are presented in section two. Section three presents the literature review, followed by model specification and sources of data in section four. Section five discusses the empirical findings and policy implications and finally section six concludes.

\section{Overview of Foreign Investment and Public Expenditure in Malaysia}

Foreign investment played a vital role in the process of industrialisation in Malaysia as early as the 1960s during which the emphasis was given on the development of import substitution industries. Various initiatives were taken to attract foreign investment, such as the granting of tax holidays, the development of industrial estates and other related infrastructures, and the imposition of tariff protection. As a result, the import substitution phase was at the outset dominated by foreign companies producing consumer products using imported technologies from their parent companies (Anuwar, 1992).

In 1970s, Malaysia shifted its industrialisation strategy from import substitution to export-oriented, due to a relatively small domestic market. Foreign investment was expected to continuously play important roles not only as a source capital, management expertise, and industrial technology, but also as a means to access overseas markets. 1986 witnessed the introduction of the Promotion of Investments Act in replacement of the 1968 Investment Incentive Act as an important policy instrument to attract more foreign investment into the export sector (Anuwar, 1992). Several changes were made to liberalise foreign investment policy, such as the introduction of new fiscal incentives and equity guidelines. Among significant policy changes made were the exemption of manufacturing companies with shareholder's funds of less than RM2.5 million or 75 workers from being licensed, and the acceptance of $100 \%$ foreign ownership of capital to companies which export more than $50 \%$ (previously $80 \%$ ) of their products.

Significant changes in foreign investment policies in 1986, have successfully attracted large inflow of foreign investments, especially the export-oriented foreign companies, into the manufacturing sector and has improved production efficiency (Malaysia, 1991). This can be seen in Figure 1, which shows that real foreign investment inflow (1990 constant prices) recorded the highest rate of growth in 1987.

IJMS 17 (1), 1-18 (2010) 


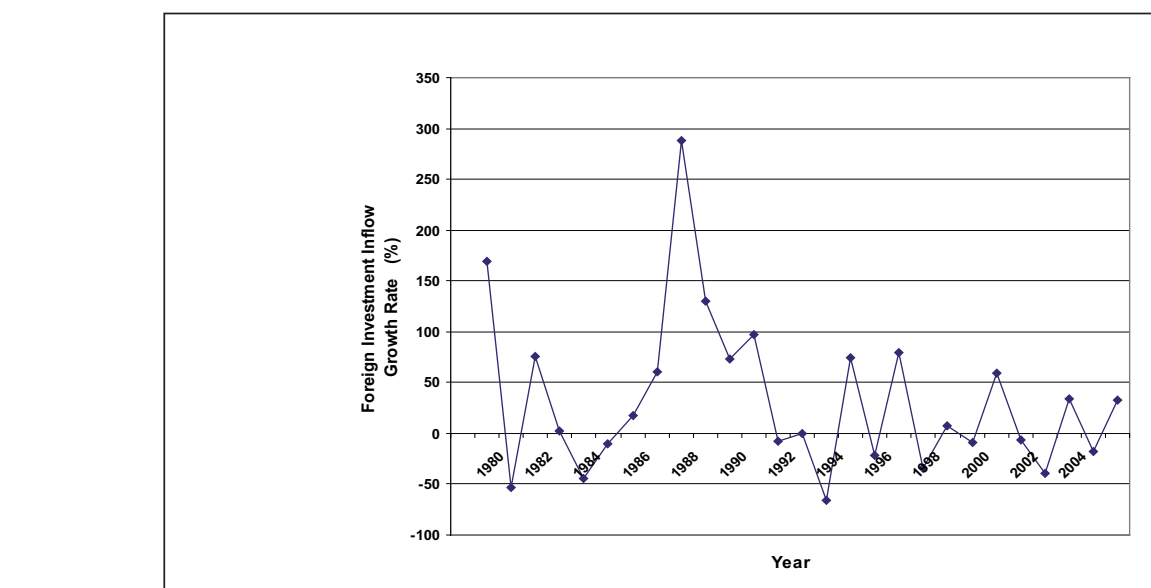

Figure 1. The growth rates of foreign investment inflow into Malaysia, 1978-2005.

With regard to the origin of foreign investment inflows, Table 1 shows that United States, Japan, and Singapore were the principle sources. United States' share of total foreign investment was about $18.6 \%$ in 1978 and increased to $29.3 \%$ in 2005. United Kingdom ranked the third most important source of foreign investment in Malaysia in 1978. However, its share slipped from $11.2 \%$ in 1978 to only $0.6 \%$ in 2005 . Most of the foreign investment inflow in Malaysia concentrated in the electrical and electronic products industry which accounted for about $63.3 \%$ of the total foreign investment inflow in 2005 (Table 2).

Table 1

Foreign Investment in Malaysia by Country of Origin, 1978 and 2005 (RM Million)

\begin{tabular}{|c|c|c|}
\hline Country & 1978 & 2005 \\
\hline United States & 33.0 & 5155.0 \\
\hline Japan & 25.2 & 3671.7 \\
\hline Singapore & 13.4 & 2919.9 \\
\hline Korea & 0.2 & 673.6 \\
\hline Taiwan & - & 430.7 \\
\hline Germany & 9.8 & 387.7 \\
\hline Australia & 4.1 & 155.9 \\
\hline Hong Kong & 9.7 & 105.4 \\
\hline United Kingdom & 19.9 & 99.2 \\
\hline Indonesia & 0.2 & 52.5 \\
\hline Others & 62.3 & 4231.3 \\
\hline Total & 177.8 & 17882.9 \\
\hline
\end{tabular}

Source. Malaysia (1983 \& 2006).

4 IJMS 17 (1), 1-18 (2010) 
Table 2

Foreign Investment in Malaysia by Industry, 1978 and 2005 (RM Million)

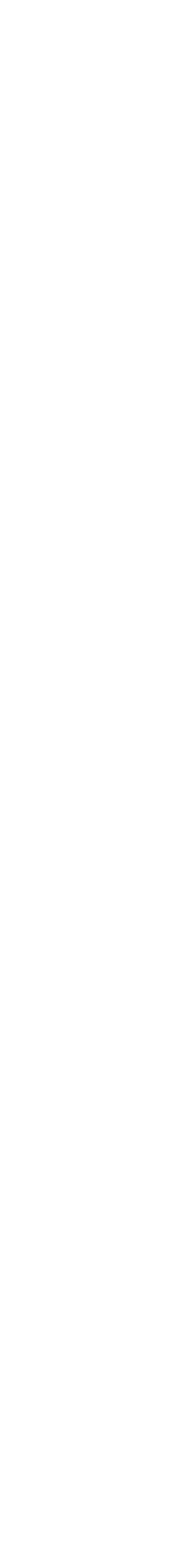

\begin{tabular}{lrc}
\hline Industry & 1978 & 2005 \\
\hline Electrical \& Electronic Products & 61.4 & 11318.9 \\
Chemicals \& Chemical Products & 7.4 & 869.5 \\
Non-Metallic Mineral Products & 8.0 & 596.1 \\
Food Manufacturing & 34.6 & 531.9 \\
Transport Equipment & 0.5 & 503.8 \\
Basic Mineral Products & 2.1 & 430.5 \\
Fabricated Metal Products & 28.0 & 250.6 \\
Rubber Products & 8.6 & 216.2 \\
Textiles \& Textile Products & 4.2 & 146.2 \\
Petroleum Products & 1.6 & 133.0 \\
Paper, Printing \& Publishing & 0.4 & 68.3 \\
Miscellaneous & 21.0 & 2763.5 \\
\hline Total & 177.8 & 17882.9 \\
\hline
\end{tabular}

Source. Malaysia (1983 \& 2006).

Besides creating a conducive environment for the growth of private sector's investment, the government also participates actively in the economy. The introduction of the First Outline Perspective Plan 1971-1990, to correct socioeconomic imbalances, witnessed the change in the degree of government intervention in the economy from a passive to more active role. In order to eliminate poverty and accelerate the process of restructuring the society, extensive use of public enterprises and joint ventures with the private sector had been resorted to. Apart from providing public utilities and infrastructure, the government participated in various economic activities and was also involved in the development of heavy industries.

These had resulted in the enlargement of the public sector which covered the period of Second (1970-1975), Third (1976-1980), and Fourth (1981-1985) Malaysia Plans. However, poor performance of many public enterprises and economic recession experienced in 1985 had induced the government to introduce the Malaysia's Privatisation Policy in 1983 (Rugayah, 1991; Salih \& Yusof, 1989). This led to gradual cut down in the size of public sector and beginning with the Fifth Malaysia Plan (1986-1990), the government encouraged the private sector to take the leading role in developing the economy.

Figure 2 shows the decreasing trend of the size of public sector as measured by the ratio of government development expenditure to GDP. Government development expenditure covers expenditure on security (defence and

IJMS 17 (1), 1-18 (2010) 5 
internal security), social services (education, health, and housing), economic services (agricultural and rural development, public utilities, commerce and industry, transport, and communication), and general administration. Government development expenditure as a percentage of GDP was reduced from an annual average of $13.23 \%$ during $1978-1985$ to only $7.4 \%$ of GDP during 1986-2005.

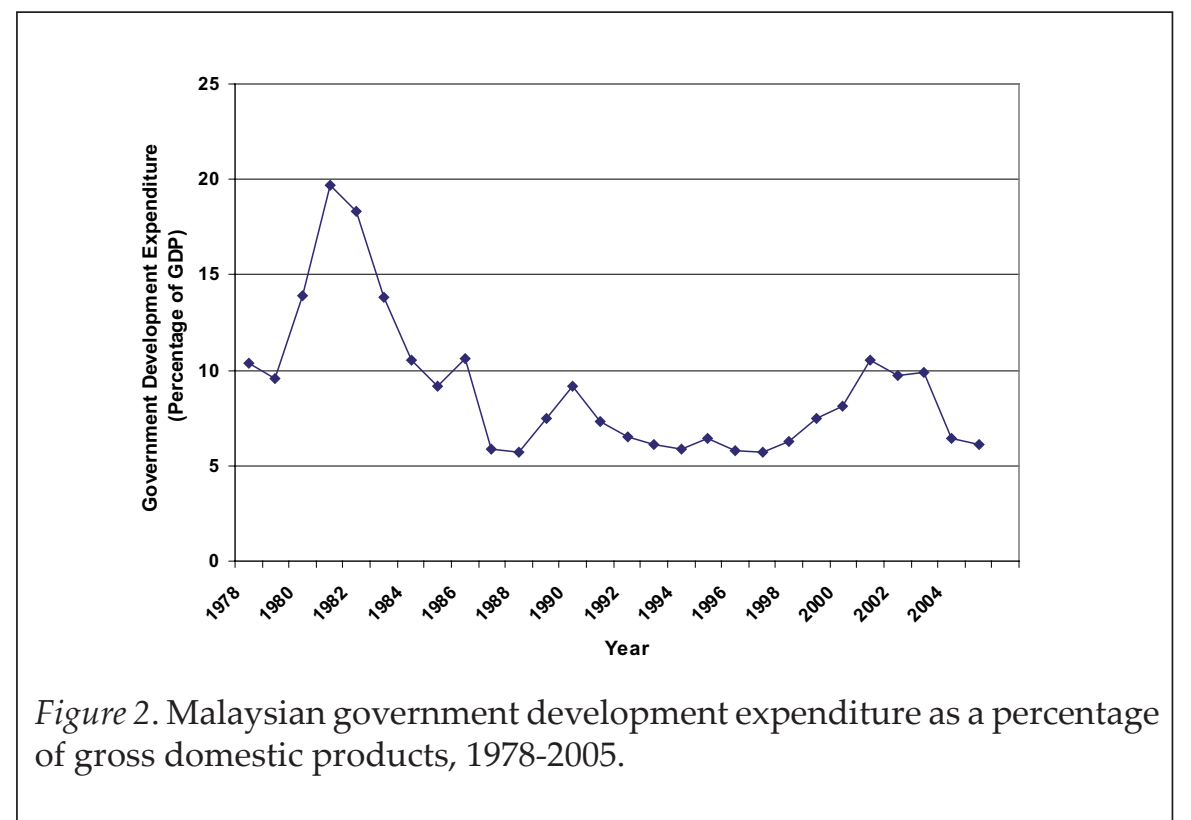

\section{Literature Review}

Several studies which examined the relationship between FDI and economic growth suggested that the degree of the FDI impact on economic growth depends on the absorptive capacity of the host country (Balasubramanyam, Salisu, \& Sapsford, 1996; Borensztein, Gregoria, \& Lee, 1998; Zhang, 2001; Durham, 2004; Le \& Suruga, 2005). Balasubramanyam et al. (1996) found that FDI contributed more to economic growth in countries that adopt export promotion than those adopt import substitution strategy. This confirmed earlier hypothesis suggested by Bhagwati (1978). Nair-Reichert and Weinhold (2001) found that open economies have higher contribution of FDI to the economic growth.

Borensztein et al. (1998) showed that FDI contributes to economic growth only when the host country has achieved certain threshold stock of human capital. Zhang (2001) found that besides liberalised trade regime and

6 IJMS 17 (1), 1-18 (2010) 


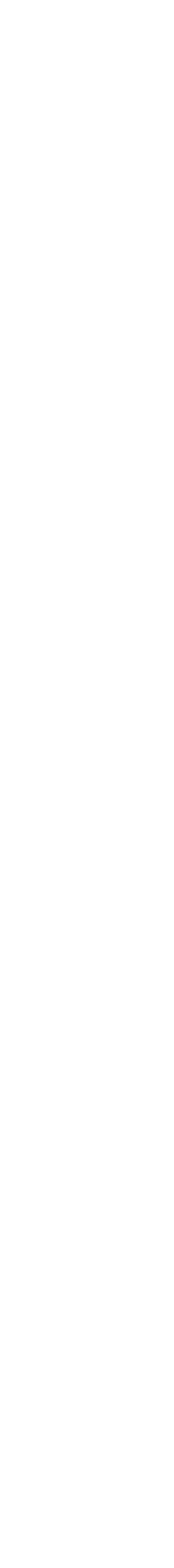

improved education, FDI is more likely to promote economic growth when host countries encourage export-oriented FDI and maintain macroeconomic stability. Durham (2004) showed that the positive effect of FDI on economic growth depends on the degree of the host countries' financial or institutional development. In a study of 105 developing and developed countries for the period 1970-2001, Le and Suruga (2005) found that FDI, public expenditure, and private investment play an important role in promoting economic growth. However, excessive government intervention hinders the beneficial effects of FDI on economic growth.

A number of studies have been carried out to empirically investigate the impact of public expenditure on economic growth and produced varying results. A study by Kormendi and Meguire (1985) on the impact of government consumption expenditure on growth rates of real GDP in 47 countries during the post-World War II period found no significant relationship between the two variables.

Landau (1983), on the other hand, found a negative relationship between the share of government expenditure in GDP and economic growth for a cross-section of 96 LDCs and developed countries over various time periods between 1961 and 1976. When dividing government expenditure into five categories, viz. consumption, education, defence, transfers, and capital expenditure, Landau (1986) found that each type of government expenditure had either significant negative or insignificant positive impact on the growth of GDP per capita. A similar negative relationship result between government consumption spending and economic growth was found by Barro (1991) for 98 countries during the period 1960-1985.

Several other studies found a positive impact of public expenditure on productivity and economic growth (Grier \& Tullock ,1989; Aschauer, 1989; Munnell, 1990; Barro, 1991; Easterly \& Rebelo, 1993; Devarajan, Swaroop, \& Zou, 1996; Doessel \& Valadkhani, 2003; Le \& Suruga, 2005). Using data for 24 OECD countries during 1951-1980 and 89 other countries during 1961-1980, Grier and Tullock (1989) found a positive effect of government expenditure on economic growth in Asian countries and a negative effect in $\mathrm{OECD}$, African, and American countries.

In a study of 43 developing countries during 1970-1990, Devarajan et al. (1996) found that government current expenditure appeared to have a positive effect on economic growth while government capital expenditure gave a negative impact. In contrast, a recent study by Le and Suruga (2005) found a positive impact of public capital expenditure and a negative effect of public non-capital expenditure on economic growth of 105 developing and developed countries for the period 1970-2001. In a study on the effect 
of government on economic growth, Doessel and Valadkhani (2003) found government consumption expenditure exerted a strong positive impact on Fiji's economic growth during 1964-1999.

Past studies on Malaysian economic growth can be grouped into studies that attempted to identify sources of Malaysian economic growth (whether input-driven or productivity-driven growth) and studies that examined the determinants of economic growth. Included in the first category were studies by Ikemoto (1986), World Bank (1993), Gan and Robinson (1993), Kawai (1994), Tham (1997), Gan and Soon (1998), Taylor and Lewis (2001), and Jenny (2001). Despite differences in data, periods of study, and methodologies employed, their findings led to a similar conclusion. The rapid transformation of the Malaysian economy has been almost entirely due to the growth in factor inputs, particularly through capital accumulation.

Studies which examined the determinants of Malaysian economic growth include the work done by, among others, Momodou (1993), Rahmah (1998, 1999, \& 2003), Masron (2001), Kew (2003), Choong, Yusop and Soo (2005), and Maamor, and Sahlan (2006). By including FDI, gross domestic saving and external debt as variables, Momodou (1994) found positive impact of FDI on Malaysian economic growth during the period 1961-1990. Kew's (2003) finding also revealed that Malaysian economic growth during 19802000 was determined by FDI and exports. Choong et al. (2005) examined the impact of FDI on Malaysian economic growth through a channel of financial system development during 1970-2001. They found that improvement of technology level in Malaysia in the long run was due to the FDI's spillover efficiency effects.

Besides variables such as domestic saving, export, and population, Rahmah (1999), included government expenditure on education in her economic growth model. She found positive impact of government expenditure and export and negative impact of population growth on Malaysian economic growth during 1970-1996. Maamor and Sahlan (2006) also included government expenditure on education and health as explanatory variables in their model and found positive impact of government expenditure on Malaysian economic growth during 1970-2004. Wai (2002), on the other hand, examined the behavioral relationships between public expenditure and Malaysian national income during 1970-2000 and found positive causal effects from public expenditure on national income.

\section{Model Specification and Data}

The model was analysed using two common techniques, namely the Augmented Dickey-Fuller (ADF) and Ordinary Least Square (OLS)

8 IJMS 17 (1), 1-18 (2010) 


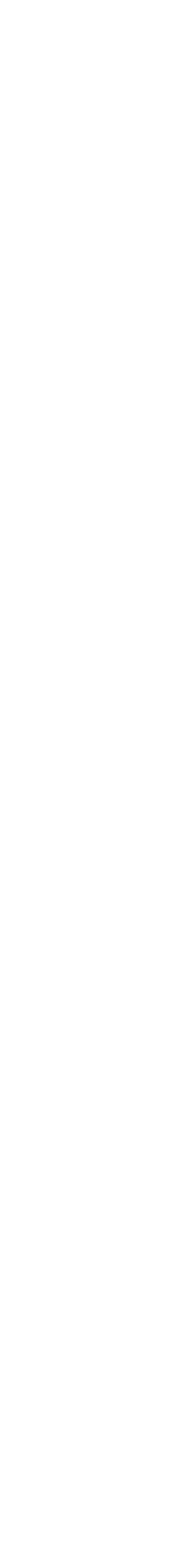

parametric estimation (Dickey \& Fuller, 1979; Gujarati, 1995). In order to establish a sensible relationship between variables, it is necessary to test for stationarity of the series in the model since non-stationary series can lead to a spurious regression estimation. The relationship between the variables may not reflect the true relationship, but a high correlation would suggest that strong trends are present in the variables. Only when the variables are stationary, the OLS estimation would be meaningful and appropriate.

We can determine whether each of the vector components of $X_{t}$ is nonstationary or otherwise by applying the ADF test. If we denote the $i^{\text {th }}$ component of $X_{t}$ by $X_{t}^{(i)},(i=1,2,3, \ldots, k)$, the ADF test for each of the components is performed by estimating the following regression equation:

$$
\Delta Y_{t}=\alpha+\gamma t+\rho Y_{t-1}+\sum_{i=1}^{k} \beta_{i} \Delta X_{t-1}^{(i)}+\xi_{t}
$$

where $Y_{t}$ is the dependent variable, and $X_{t}$ is the vector of $k$ independent variables. The $\xi_{t}$ is a white-noise process; and the null hypothesis that $Y_{t}$ contains a unit root is rejected when the estimated coefficient of the lagged variables, $\rho$, is statistically less than zero.

The econometric model used here was based on the studies of Devarajan et al. (1996), Borensztein et al. (1998), and Le and Suruga (2005), which can be specified by equation (2) with $X_{t}=\left[F I_{t^{\prime}} G O V_{t^{\prime}} E_{t^{\prime}} P O P_{t}\right]^{\mathrm{T}}$, such that in the absence of the time trend term:

$$
Y_{t}=\alpha+\rho Y_{t-1}+\beta_{1} F I_{t}+\beta_{2} G O V_{t}+\beta_{3} E_{t}+\beta_{4} P O P_{t}+\varepsilon_{t}
$$

where:

$Y=$ the growth rate of real gross domestic product (GDP) per capita;

$F I \quad=$ the foreign investment as a percentage of GDP;

$G O V=$ the government development expenditure as a percentage of GDP;

$E \quad=$ the growth rate of real export;

$P O P=$ the growth rate of population;

$t \quad=$ year; and

$\varepsilon \quad=$ the error term.

The economic growth is measured by the growth rate of real GDP per capita. Besides foreign investment and government development expenditure, we have also included lagged real GDP per capita, the growth rates of real export and population as control variables which are often considered in empirical research on economic growth. The current values of GDP, foreign investment, and export are deflated by consumer price index using 1990 as

IJMS 17 (1), 1-18 (2010) 9 
the base year. The main source of time-series data for this study was drawn from various issues of the Economic Report published by the Ministry of Finance. Equation (2) was estimated by utilising the OLS technique for the time period of 1978-2005.

All variables, except the population growth rate, were expected to have positive impact on economic growth. The neo-classical growth model predicts that population growth has an adverse effect on economic growth. The inability of the economy with a growing population to generate enough - saving and investment to equip the additional workforce would reduce the overall productivity and hence retard the economic growth (Van Den Berg, 2001).

Export represents economic openness. It has often been cited in the literature as an important factor in enhancing economic growth of small open economies, such as Malaysia (Ghatak, Milves, \& Utkulu, 1997; Baharumshah \& Rashid, 1999). Expansion of export markets encourages countries to specialise in producing goods and services that they have comparative advantage. This would result in efficient production and increased factor productivity through better utilisation of capacity and economies of scale (Helpman \& Krugman, 1985). Export helps to alleviate a country's foreignexchange constraint and facilitates importation of capital and intermediate inputs which are necessary for the country's economic growth (Iscan, 1998; Damooei \& Tavakoli, 2006).

Table 3 presents descriptive statistics of the variables used in this study. During 1978-2005, the average growth rate of real GDP per capita was $4.20 \%$ and its growth rate varied from a minimum of negative $11.45 \%$ to an unprecedented value of $15.06 \%$. The negative growth coincided with the 1986 recession due to the collapse of Malaysian primary commodity prices. Foreign investment and government development expenditure averaged at $4.33 \%$ and $9.07 \%$ of GDP respectively. Growth rate of real export was quite high, averaging at $10.63 \%$ and recorded a minimum growth of negative $10.65 \%$ during 1980 s recession. The population grew at an average of $2.55 \%$.

Table 3

Descriptive Statistics

\begin{tabular}{crrc}
\hline Variables & Mean & Minimum & Maximum \\
\hline Y & 4.20 & -11.45 & 15.06 \\
FI & 4.33 & 0.35 & 15.25 \\
GOV & 9.07 & 5.73 & 19.71 \\
E & 10.63 & -10.65 & 35.22 \\
POP & 2.55 & 1.69 & 3.44 \\
\hline
\end{tabular}




\section{Estimation Results}

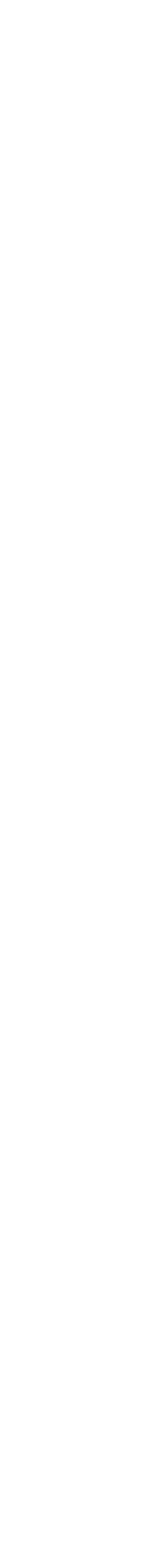

Table 4 presents the results of ADF unit root test in the levels and first differences for $Y, F I, G O V, E$, and POP. The purpose of this test was that, all the series should be non-stationary in the levels and stationary at the first difference. It was also implied that it would be worthwhile to conduct tests of the unit root in order to determine whether variables are stationary or integrated. Hence, testing for the presence of a unit root is the first step in the empirical investigation.

As reported in Table 4, the series are non-stationary in their level form since the null hypothesis of the unit root cannot be rejected at conventional significance levels. However, when the same tests were applied on the first difference, we found no evidence of unit root for all the series under investigation. Thus, all the series are stationary after first differences, that is, they are integrated of first order and thereby implying an $I(1)$ process.

Table 4

Augmented Dickey-Fuller Unit Root Tests

\begin{tabular}{ccccccc}
\hline \multirow{2}{*}{ Variables Level } & \multicolumn{3}{c}{ First Difference } \\
\cline { 2 - 7 } & $\tau_{\tau}(\mathrm{ADF})$ & $\tau_{\mu}(\mathrm{ADF})$ & $\tau(\mathrm{ADF})$ & $\tau_{\tau}(\mathrm{ADF})$ & $\tau_{\mu}(\mathrm{ADF})$ & $\tau(\mathrm{ADF})$ \\
\hline$Y$ & $-2.160[3]$ & $-2.177[3]$ & $-1.076[3]$ & $-6.349[1]^{* * *}$ & $-6.325[1]^{* * *}$ & $-6.484[1]^{* * *}$ \\
$F I$ & $-1.812[6]$ & $-0.689[6]$ & $-0.249[6]$ & $-4.036[2]^{* * *}$ & $-3.331[5]^{*}$ & $-4.074[2]^{* * *}$ \\
GOV & $-1.579[0]$ & $-2.044[0]$ & $-0.902[0]$ & $-3.863[0]^{* * *}$ & $-3.795[0]^{* *}$ & $-3.933[0]^{* * *}$ \\
$E$ & $-1.916[6]$ & $-1.599[6]$ & $-0.314[6]$ & $-6.834[2]^{* * *}$ & $-6.594[2]^{* * *}$ & $-7.016[2]^{* * *}$ \\
$P O P$ & $-0.162[4]$ & $-0.718[9]$ & $-0.877[4]$ & $-2.646[4]^{*}$ & $-6.937[0]^{* * *}$ & $-5.596[3]^{* * *}$ \\
\hline
\end{tabular}

Notes. ${ }^{*}, * *$ and $* *$ denote significance at $10 \%, 5 \%$ and $1 \%$ levels respectively. ADF stands for Augmented Dickey Fuller; $\tau_{\mu}$ represents the most general model with a drift and trend; $\tau_{\tau}$ is the model with a drift and without trend; $\tau$ is the most restrictive model without a drift and without trend. Numbers in brackets are number of lags used in the ADF test in order to remove serial correlation in the residuals.

Since the test of unit root suggested that all the variables are stationary at the first difference, we proceeded with the OLS estimation and the result is presented in Table 5. The $\mathrm{R}^{2}$ from the estimated regression was 0.82 . This implied that about $82 \%$ of the variation in $Y_{t}$ is explained by the variation in the independent variables included in the model. In the presence of lagged dependent variable in our model, the Durbin Watson $d$-statistic was no longer appropriate to test for autocorrelation. Instead we used the Durbin Watson $h$-statistic and the result showed no evidence of autocorrelation at $95 \%$ confidence interval. No evidence of heteroskedasticity was also found in the residuals based on the White test. The Jarque-Bera test confirmed that the estimated residual is normally distributed. 
The coefficients of all explanatory variables were statistically significant and exhibited their expected signs. Our result indicated that export growth has had a highly significant (at 1\% level) positive impact on economic growth. An increase of one unit or percentage point of rate of growth of export will increase economic growth by 0.493 percentage point. The estimated coefficient of the growth rate of real export which is larger than the coefficients of other explanatory variables suggested that the growth of the Malaysian economy is an export-led growth. The important implication is that export plays an important role in the Malaysian economy.

This result is consistent with those obtained in other studies. Using data from 1970-1996, Rahmah (1999) found that an increase of one percentage point of rate of growth of real export would increase Malaysian real GDP between 0.125 to 0.136 percentage point. Studies by Shah and Yusoff (1990), Doraisami (1996), Ghatak et.al (1997), and Khalafalla and Webb (2001) found support for the export-led growth hypothesis for the Malaysian economy. Liu, Liu, and Wei (2005) studied the Malaysian economy over the period 1970-1998 and found that Malaysia enjoyed highest economic performance during this period due to its highest degree of openness. Various empirical studies in other countries also showed positive impact of export on economic growth (Balassa, 1978; Dollar, 1992; Sachs \& Werner, 1995; Park \& Prime, 1997).

Both government development expenditure and foreign investment have significant positive impact on economic growth rate. However, with respect to the magnitude of the coefficients, government development expenditure has a very large impact in promoting Malaysian economic growth relative to foreign investment. An increase of one percentage point of government development expenditure would increase output growth by 0.430 percentage point as compared to only 0.213 percentage point due to increase in foreign investment. This suggested that increase in the degree of government involvement in the economy has greater impact in stimulating Malaysian economic growth as compared to foreign investment. Hence, active government participation has produced desirable result in driving - the Malaysian economy to higher economic growth.

The result also showed that last year growth in income per capita increases current economic growth by 0.206 percentage point. This suggested that more rapid economic growth has had a stimulative long-run effect on the future economic growth of the country. Population growth has a significant large negative impact on Malaysian economic growth. An increase of one percentage point of population growth will reduce economic growth by 3.841 percentage point. This implied that even a small increase in population would slow the Malaysian economic growth rapidly. The finding of negative

12 IJMS $17(1), 1-18(2010)$ 
impact of population growth on economic growth is consistent with earlier findings by Rahmah (1998, 1999, \& 2003). Rahmah (1999) found that an increase of one percentage point of population growth reduced Malaysian economic growth by 3.730 to 3.855 percentage point during 1970-1996. This finding is also consistent with findings in other countries (Landau, 1986; Durham, 2004; Datta \& Agarwal, 2004).

Table 5

Regression Result of Equation (2)

\begin{tabular}{|c|c|}
\hline $\begin{array}{c}Y_{t}=2.783+0.206 Y_{t-1} \\
(0.77) \quad(1.81)^{*}\end{array}$ & $\begin{array}{c}0.213 F I_{t}+0.430 G O V_{t}+0.493 E_{t}-3.841 P O P \\
(2.01)^{*} \\
(2.24)^{* *}\end{array}$ \\
\hline$R$-squared & $=0.82$ \\
\hline Adjusted $R$-squared & 0.77 \\
\hline Standard error of regression & $=2.76$ \\
\hline$F$-statistic & $=16.41$ \\
\hline Durbin-Watson statistic & $=2.04$ \\
\hline White test & $=0.23$ \\
\hline Jarque-Bera normality test & $=6.76^{* *}$ \\
\hline Sum of squared residuals & $=159.50$ \\
\hline
\end{tabular}

Notes. Figures in parentheses are $t$-statistics.

* Significant at the $10 \%$ level.

** Significant at the 5\% level.

*** Significant at the $1 \%$ level.

\section{Conclusion and Policy Implications}

The study examined the impact of foreign investment and government development expenditure on Malaysian economic growth during 1978-2005. Besides foreign investment and government development expenditure, lagged real GDP per capita, the growth rates of real export, and population have also been included as control variables. The regression results showed that the coefficients of all explanatory variables are statistically significant and exhibit their expected signs. Export growth was found to have a highly significant positive impact on GDP per capita growth in Malaysia. This suggested that export sector plays a leading role as an engine of economic growth and development for the country.

Even though foreign investment and government development expenditure have positive impact on Malaysian economic growth, the impact of government development expenditure on GDP per capita growth is larger than the impact of foreign investment. This result indicated that besides export, government expenditure plays an important role in promoting 
economic growth. This finding supported the success of credible fiscal adjustment in improving Malaysian economic performance. However, in order to ensure the maximum stimulus of government development expenditure on economic growth, priorities have to be given to undertake projects which are highly productive and continuously upgrade leadership capacities and initiatives in managing and organising scarce resources in the public sector. The less overwhelming impact of foreign investment in stimulating Malaysian economic growth could be overcome through continuously liberalising the foreign investment policy.

담

Previous year of real income per capita growth was found to have a stimulative long-run effect on the future economic growth of the country. Population growth exerts a significant negative impact on economic growth. This implied that slower population growth would significantly increase economic growth. However, given that the Malaysian population growth is considerably low at an average of $2.6 \%$, a further decrease in population growth would not help economic growth in the long run, since this would contribute to serious shortage of manpower. Shortage of labour supply would lead to underutilisation of non-labour resources and hence retard economic growth (Gillis, Perkins, Roemer, \& Snodgrass, 1996; Van Den Berg, 2001).

\section{References}

Anuwar, A. (1992). Malaysia's industrialization: The quest for technology. Singapore: Oxford University Press.

Aschauer, D.A. (1989). Is public expenditure productive? Journal of Monetary Economics, 23, 177-200.

Baharumshah, A.Z., \& Rashid, S. (1999). Exports, imports and economic growth in Malaysia: Empirical evidence based on time series. Asian Economic Journal, 13(4), 389-406.

a

Balassa, B. (1978). Exports and economic growth, further evidence. Journal of Development Economics, 5(2), 181-189.

- Balasubramanyam, V.N., Salisu, M., \& Sapsford, D. (1996). FDI and growth in EP and IS countries. Economic Journal, 106, 92-105.

Barram, E., \& Ward, B. (1993). The externality effect of government expenditure on investment in OECD countries. Applied Economics, 25, 711-716.

Barro, R.J. (1991). Economic growth in a cross section of countries. Quarterly Journal of Economics, 106, 407-443.

Bhagwati, J.N. (1978). Anatomy and consequences of exchange control regimes. Studies in International Economic Relations, 1(2). New York: National Bureau of Economic Research.

14 IJMS 17 (1), 1-18 (2010) 


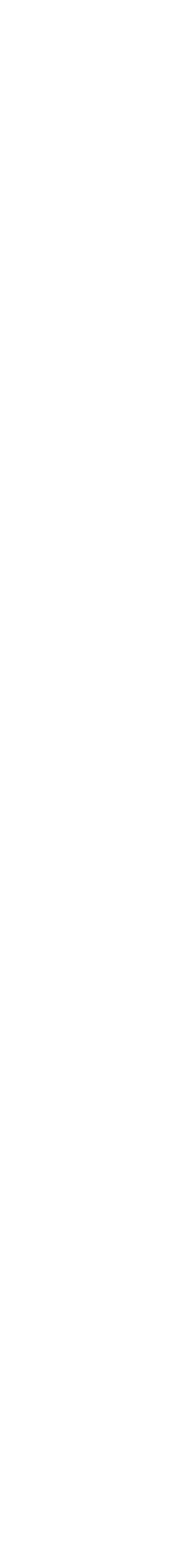

Borensztein, E., Gregorio, J.D., \& Lee, J-W. (1998). How does FDI affect economic growth? Journal of International Economics, 45, 115-135.

Choong, C.K., Zulkornain Yusop, \& Soo, S.C. (2005). Foreign direct investment and economic growth in Malaysia: The role of domestic financial sector. Singapore Economic Review, 50 (2), 245-268.

Damooei, J., \& Tavakoli, A. (2006). The effects of foreign direct investment and imports on economic growth: A comparative analysis of Thailand and the Philippines (1970-1998). The Journal of Developing Areas, 39(2), 79-100.

Datta, A., \& Agarwal, S. (2004). Telecommunications and economic growth. Applied Economics, 36, 1649-1654.

De Mello, L.R. (1997). Foreign direct investment in developing countries and Growth: A selective survey. Journal of Development Studies, 34(1), 1-34.

Devarajan. S., Swaroop, V., \& Zou, H. (1996). The composition of public expenditure and economic growth. Journal of Monetary Economics, 37(2), 313-344.

Dickey, D.A., \& Fuller, D.A. (1979). Distributions of the estimators for autoregressive time series with a unit root. Journal of American Statistical Association, 74, 427-431.

Doessel, D.P., \& Valadkhani, A. (2003). The effect of government on economic growth in Fiji. Singapore Economic Review, 48(1), 27-38.

Dollar, D. (1992). Outward-oriented developing economics really do grow more rapidly. Economic Development and Cultural Change, 40, 523-544.

Doraisami, A. (1996). Export growth and economic growth: A re-examination of some time-series evidence of the Malaysian experience. Journal of Developing Areas, 30, 223-230.

Durham, J.B. (2004). Absorptive capacity and the effects of FDI and equity portfolio investment on economic growth. European Economic Review, 48, 285-306.

Easterly, W., \& Rebelo, S. (1993). Fiscal policy and economic growth: An empirical investigation. Journal of Monetary Economics, 32, 417-58.

Gan, W.B., \& Robinson, E. (1993). Aggregate supply and wage price mechanism: Some implications for inflation stabilisation in Malaysia. Work paper presented at the HIID-ISIS Seminar, Kuala Lumpur.

Gan, W.B., \& Soon, L.Y. (1998). Input versus productivity driven growth: Implications for the Malaysian economy. In L.Y., Soon, \& N. Shyamala (Eds.), The Seventh Malaysia Plan: Productivity for sustainable development. Kuala Lumpur: University of Malaya Publisher, 39-57.

Ghatak, S., Milner, C., \& Utkulu, U. (1997). Exports, export composition and growth: Cointegration and causality evidence for Malaysia. Applied Economics, 29(2), 213-223.

Giannaros, D., Kolluri, B., \& Panik, M. (1999). An empirical analysis of the effects of government spending on capital investment: Evidence from OECD countries. International Economic Journal, 13, 45-55. 
Gillis, M., Perkins, D.H., Roemer, M., \& Snodgrass, D.R. (1996). Economics of development (4th ed.). New York: W. W. Norton.

Grier, K., \& Tullock, G. (1989). An empirical analysis of cross-national economic growth, 1951-1980. Journal of Monetary Economics, 24, 259276.

Gujarati, D.N. (1995). Basic econometrics (3rd ed.). New York: McGraw-Hill.

Helpman, E., \& Krugman, P. (1985). Market structure and foreign trade. Cambridge: MIT Press.

Ikemoto, Y. (1986). Technical progress and level of technology in Asian countries, 1970-1980: A translog index approach. Developing Economies, 24(4), 368-390.

Iscan, T. (1998). Trade liberalization and productivity: A panel study of the Mexican manufacturing industries. The Journal of Development Studies, 34(5), 123-148.

Jenny, C.Y.C. (2001). Total factor productivity growth in Malaysia, 1971-1999. (Unpublised Master of Economics Thesis). Faculty of Economics and Administration, University of Malaya.

Kawai, H. (1994). International comparative analysis of economic growth: Trade liberalisation and productivity. Developing Economies, 11(4), 373397.

Kew, W.C. (2003). Foreign direct investment, exports and macroeconomic performance in Malaysia: A causality analysis. (Master of Economics Dissertation). Faculty of Economics and Administration, University of Malaya.

Khalafalla, K.Y., \& Webb, A.J. (2001). Export-led growth and structural change: Evidence from Malaysia. Applied Economics, 33, 1703-1715.

Kormendi, R.C., \& Meguire, P.G. (1985). Macroeconomic determinants of growth: Cross country evidence. Journal of Monetary Economics, 16, 141-163.

Landau, D. (1983). Government expenditure and economic growth: A cross country study. Southern Economic Journal, 49, 783-792.

Landau, D. (1986). Government and economic growth in the less developed countries: An empirical study for 1960-1980. Economic Development and Cultural Change, 35 (1), 35-75.

Le, M.V., \& Suruga, T. (2005). Foreign direct investment, public expenditure and economic growth: the empirical evidence for the period 19702001. Applied Economics Letters, 12, 45-49.

Levine, R., \& Renelt, D. (1992). A sensitivity analisis of cross-country growth regression. American Economic Review, 82 (4), 942-963.

Liu, G.S., Liu,X., \& Wei,Y. (2005). Openness and efficiency of Malaysia, India and China relative to the world economy: A comparative study. Malaysian Journal of Economic Studies, 42(1 \& 2), 41-61.

Maamor, S., \& Sahlan, R. (2006). Perbelanjaan Kerajaan, Pembentukan Modal Manusia dan Pertumbuhan Ekonomi Negara. Paper presented 


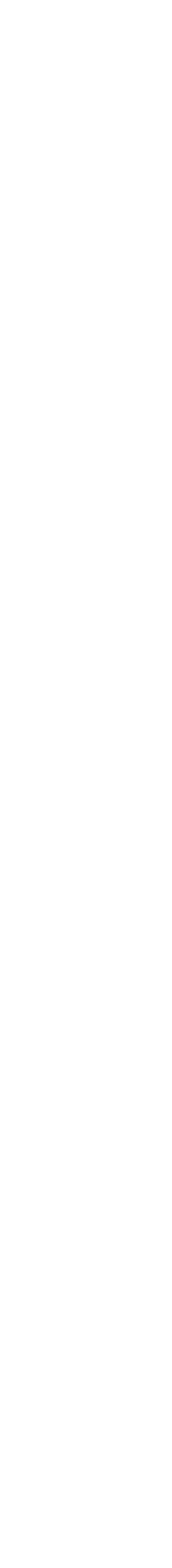

at the Persidangan Kebangsaan Ekonomi Malaysia, Universiti Kebangsaan Malaysia, Port Dickson, 11-13 Disember 2006.

Malaysia. (1983). Economic Report 1983/84. Kuala Lumpur: Ministry of Finance.

Malaysia. (2006). Economic Report 2006/07. Putrajaya: Ministry of Finance.

Masron, T.A. (2001). Kajian empiris ke atas perhubungan pelaburan langsung asing, tabungan dan pertumbuhan ekonomi. (Unpublished Master of Economics Thesis). Faculty of Economics and Administration, University of Malaya.

Momodou, C.L (1994). The role of direct foreign investment in Malaysia (Master of Ecnomics Dissertation) Faculty of Economics and Administration, University of Malaya.

Munnell, A.H. (1990). Why has productivity declined? Productivity and public investment. New England Economic Review, January / February, 3-22.

Nair-Reichert, U., \& Weinhold, D. (2001). Causality tests for cross-country panels: A new look at FDI and economic growth in developing countries. Oxford Bulletin of Economics and Statistics, 63(2), 153-172.

Park, J.H., \& Prime, P.B. (1997). Export performance and growth in China. A cross provincial analysis. Applied Economics, 29(10). 1353-1363.

Rahmah Ismail. (1998). Sumbangan pendidikan kepada pertumbuhan ekonomi Malaysia, 1970-1996. Jurnal Ekonomi Malaysia, 32, 3-20.

Rahmah Ismail. (1999). Long-term growth in Malaysia: An application of endogenous neoclassical growth model. Jurnal Ekonomi Malaysia, 33, 105-121.

Rahmah Ismail. (2003). Pendidikan dan pembangunan. Dalam Rahmah Ismail (Ed.), Ekonomi pembangunan: Isu sumber manusia. Bangi: Penerbit Universiti Kebangsaan Malaysia, 92-118.

Rugayah, M. (1991). Comparative performance of public and private enterprises in Malaysia. (Unpublished Dissertation PhD). University of Bradford, United Kingdom.

Sachs, J., \& Werner, A. (1995). Economic reform and the process of global integration. Brookings Papers on Economics Activity, 1, 1-118.

Salih, K., \& Z.A. Yusof. (1989). Overview of the New Economic Policy and framework for a post 1990 National Economic Policy: Option. Malaysian Management Review, 24(2), 13-61.

Shah, M., \& Yusoff, M.B. (1990). Export and economic growth: A case study of Malaysia. In M.B. Yusoff (Ed.), Trade and development in Malaysia, Universiti Pertanian Malaysia, Malaysia, 83-92.

Taylor, R.J., \& Lewis, P.E.T. (2001). The effects of international trade and human capital development on TFP and economic growth in Malaysia. Paper presented at the Economic Society of Australia $13^{\text {th }}$ Annual Conference of Economists, 23-25 September, University of Western Australia. 
Tham, S.Y. (1997). Productivity, growth and development in Malaysia. Singapore Economic Review, 40(1), 41-63.

Van Den Berg, H. (2001). Economic growth and development. New York: McGraw Hill.

Wai, T.Y. (2002). An econometric analysis of the relationship between public expenditure and national income in Malaysia. (Unpublished Master of Economics Thesis). Faculty of Economics and Administration, University of Malaya.

World Bank. (1993). The East Asian miracle: Economic growth and public policy.

World Bank: Policy Research Report.

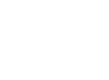

Zhang, K.H. (2001). Does foreign direct investment promote economic growth? Evidence from East Asia and Latin America. Contemporary

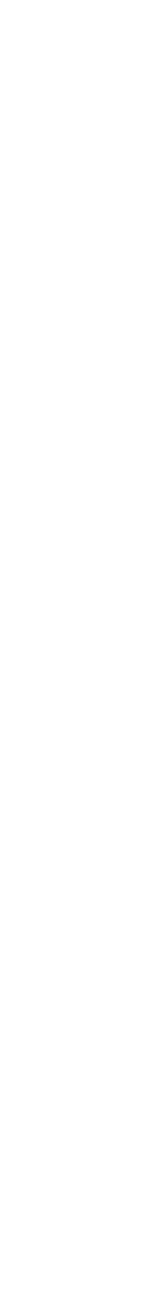
Economic Policy, 19(2), 175-185.

18 IJMS 17 (1), 1-18 (2010) 